\title{
Küçük Çocukların COVID 19 Sürecinde Teknolojik Araç Kullanımının Çeşitli Değişkenler Açısından İncelenmesi
}

\author{
Examining of Technological Tool Usage of Young Children in the COVID 19 Process in \\ Terms of Several Variables
}

\section{Ceren ARI ARAT ${ }^{1}$, Hülya GÜLAY OGELMAN ${ }^{2}$}

\footnotetext{
${ }^{1}$ Öğr. Gör., Bayburt Üniversitesi, Çocuk Bakımı ve Gençlik Hizmetleri Bölümü, cerenariarat@bayburt.edu.tr, (iD 0000-0002-5795-8901

${ }^{2}$ Prof. Dr., Sinop Üniversitesi, Temel Eğitim Bölümü, Okul Öncesi Eğitimi ABD. ogelman@sinop.edu.tr, (iD 0000-0002-4245-0208
}

\begin{tabular}{|c|c|c|c|c|}
\hline \multicolumn{5}{|c|}{ Araştırma makalesi/ Research Article } \\
\hline Geliş/ Received: 2021-02-14 & $\frac{+6}{n}$ & Kabul/ Accepted: 2021-05-21 & 絭 & Yayın/ Published: 2021-07-22 \\
\hline \multicolumn{5}{|c|}{$\begin{array}{l}\text { Atıf/ Citation } \\
\text { Ar1-Arat, C., \& Gülay-Ogelman, H. (2021). Küçük çocukların COVID-19 sürecinde teknolojik araç } \\
\text { kullanımının çeşitli değişkenler açısından incelenmesi. Maarif Mektepleri Uluslararası Eğitim Bilimleri } \\
\text { Dergisi, 5(1), 15-32. https://doi.org/10.46762/mamulebd.880109 }\end{array}$} \\
\hline
\end{tabular}

Öz

Bu çalışmada, küçük çocukların COVID 19 sürecinde teknolojik araç kullanımının çeşitli değişkenler (teknolojik araç kullanım süresi, teknolojik araç kullanım içeriklerinin kontrol edilmesi, anne çalışma durumu, anne yaşı, anne eğitim düzeyi ve çocuk sayısı) açısından incelenmesi amaçlanmıştır. Araştırmanın çalışma grubu, Bayburt ilinde okul öncesi eğitim alan ve normal gelişim özelliği gösteren 5 yaş grubundan 163 çocuk (91 kız, 71 erkek) ve annelerinden oluşmaktadır. Çalışmada, araştırmacılar tarafından geliştirilen Online Anket Formu kullanılmıştır. Veriler normal dağılım göstermediği için analizler Mann Whitney U ve Kruskal Wallis H testleri ile gerçekleştirilmiştir. Araştırmanın bulgularında; çocukların TV izleme ile toplam teknolojik araç kullanma sürelerinin anne çalışma değişkenine göre anlamlı şekilde farklılaştığı belirlenmiştir. Çocukların TV izleme süresi ile teknolojik araçların kullanma içeriklerinin anneler tarafından kontrol edilmesi, anne yaşına göre farklılaşmaktadır. Çocukların TV izleme, bilgisayar kullanma ve toplam teknolojik araç 
kullanma süreleri ile teknolojik araçların kullanma içeriklerinin kontrol edilmesinin anne eğitim düzeyine ve çocuk sayısına göre farklılaşabildiği belirlenmiştir. Sonuçlar, anne ile ilgili bazı değişkenlerin küçük çocukların teknolojik araç kullanım değişkenleri üzerinde etkili olabildiğini ortaya koymaktadır.

Anahtar Kelimeler: COVID 19, küçük çocuklar, teknolojik araç

\section{Abstract}

This study aims to examine the use of technological tool by young children during the COVID-19 process in terms of several variables (time of using a technological tool, supervision of contents when using the technological tool, mother's working status, mother's age, mother's education level and the number of siblings). The study group consists of 163 children (91 girls, 71 boys) selected among the 5-year-old children attending pre-school education in Bayburt and indicating normal development characteristics along with their mothers. In the study, an Online Survey Form developed by the researchers was used. Since the data fails to show a normal distribution, analyzes were performed by means of the Mann Whitney $U$ test and the Kruskal Wallis $\mathrm{H}$ test. Considering the findings of the study, it has been determined that the total time of watching TV and using a technological tool significantly differs according to the mother's working status variable. It has been determined that the time of watching TV and the supervision of contents of the technological tool by mothers differs according to the age of the mother. It has been further determined that the total time of watching TV, using computers and technological tool, and the supervision of contents of technological tool can differ according to the education level of the mother and the number of siblings. The results reveal that some variables related to the mother are effective on young children's use of technological tool.

Keywords: COVID 19, young children, technological tool

\section{Giriş}

Teknolojideki değişiklikler ve gelişmeler; çocukları, eğitimi ve eğitim ortamlarını önemli ölçüde etkilemektedir. Teknolojik araçların gerek eğitim gerek ev ortamında kullanılması ve çeşitliliğinin artması, bireysel olarak kullanılabilmeleri ve bilgiye ulaşmayı kolayca ulaşmayı sağlaması gibi unsurlar çocukların teknoloji kullanım alışkanlıklarını farklılaştırabilmiştir. Çocuklar son yıllarda teknolojik araçlarla daha çok zaman geçirebilmektedir. Çocukların teknolojik araçları benimsemelerinin sebeplerden biri, bu teknolojilerin toplumsal yaşamın geneline kısa bir süre içinde hızla yayılmasıdır. Son on yılda bile teknolojik araçların çeşitliliği, bu araçların sunduğu içerikte önemli değişiklikler yaşanmıştır.

2010-2025 yıl aralığında doğan ve doğacak çocukların alfa kuşağı olarak adlandırıldığı nesil için teknolojik araçlar, en önemli eğlence kaynaklarından ve eğitim ortamlarından biri olarak adlandırılabilir (Apaydın ve Kaya, 2020). Alfa kuşağı, ekranın bebek bakıcısı olduğu ilk nesil olarak tasvir edilmektedir ve bu çocuklar konuşmayla eş zamanlı olarak teknolojik araçları da kullanmayı öğrenmeye başlamaktadırlar (Yasacı ve Mustafaoğlu, 2020). Günümüz şartlarında teknoloji, çocukların hayatlarında önemli bir yer tutmaktadır. Yeni nesil çocukların, teknolojik 
araçları günlük hayatları içerisinde sıklıkla kullanıyor olmaları, onların teknolojiden nitelikli bir şekilde faydalandıklarını göstermemektedir (Özdemir ve Çebi, 2020). Dijital yerliler adını almış olan teknolojinin içine doğan yeni nesil çocukların, teknoloji ile iç içe olmaları onların bu araçları sadece doğru bilgiye ulaşma için kullandıkları anlamına gelmemektedir (Çebi ve Bahçekapılı Özdemir, 2019). Birçok yarar sağlamasının yanı sıra teknolojik araçların aşırı ve bilinçsiz bir şekilde kullanımları bazı riskleri de beraberinde getirmektedir. Okul öncesi dönem çocukları bilinçsiz kullanım ve ekrana aşırı maruz kalma ile fiziksel, sosyal, duygusal ve psikolojik açıdan zarar görebilmektedirler (Canberk ve Sağıroğlu, 2007).

Ekran süresi, teknolojik araç başında geçirilen süreyi ve aynı zamanda ekrana maruz kalma durumunu tanımlamaktadır (Lauricella, Wartella, Rideout, 2015). Amerikan Pediatri Akademisi (2016) 2 yaşın altındaki çocukların teknolojik araçlardan mümkün olduğu kadar uzak tutulmasını, 2-5 yaş aralığındaki çocukların teknolojik araç kullanım sürelerinin 1 saat ile sınırlandırılması koşulu ile anne baba denetiminde kaliteli içeriklerle sunulmasını, 6 yaşından büyük çocuklar için bu sürenin en fazla 2 saat olabileceğini ifade etmiştir. Konu ile ilgili çalışmalar, teknolojinin gelişimi, değişimi ve buna bağlı olarak kullanımıyla ilgili önemli bulgular ortaya koymaktadırlar. Örnek olarak, Türkiye İstatistik Kurumu verilerine göre masaüstü bilgisayar kullanım oran 2011 yılında \%34,3'den, 2018 yılında \%19,2'ye gerilerken diğer taraftan taşınabilir bilgisayar (tablet bilgisayar, diz üstü bilgisayar gibi) kullanımı 2004 yılında \%0,9 iken 2018 yılında \%37,9'a yükselmiştir (Öner, 2020). Benzer bir şekilde 2011, 2013 ve 2017 yıllarında 0-8 yaş çocukların teknolojik araç kullanımlarını ortaya koyan bir çalışmada (Common Sense Media, 2017), 8 yaş altı çocukların \%98'inin teknolojik araç bulunan bir evde yaşadığ belirlenmiştir. Bu oranın 2011 yılında \%50, 2013 yılında \%75 olduğu ifade edilmektedir. Küçük çocuğu olan ailelerin akıllı telefon sahibi olma oranları, 2011 yılında \%41, 2013 yılında \%63 iken 2017 yılında \%95 olarak belirlenmiştir. Bu ailelerin tablet sahibi olma oranları ise 2011 yılında \%8, 2013 yılında \%40, 2017 yılında \%78 olarak belirlenmiştir. Nitekim çocukların kendi tabletine sahip olma oranının, 2011 yılında \%1'in altında, 2013 yılında \%7, 2018 yilında ise \%42 olduğu belirtilmektedir (Common Sense Media, 2017). Konu ile ilgili yapılan araştırmalar, çocukların teknolojik araç kullanım sürelerindeki artışı ortaya koyarak bu bulguları desteklemektedir (Güngör, Gülay-Ogelman, ErtenSarıkaya ve Körükçü, 2020; Yasacı ve Mustafaoğlu, 2020).

Teknolojik araçların kullanım süreleri, amaçları, insan sağlığı ve çocuk gelişimi üzerindeki etkileri son yıllarda dikkat çeken ve sıklıkla çalışılan konular arasındadır. Teknolojik araç kullanımının çocuklar üzerinde fiziksel, sosyal, duygusal ve bilişsel etkileri bulunmaktadır. Hareketsizlik, obezite, sosyal ilişkilerin zayıflaması, günlük rutinlere zaman ayırmama gibi durumlar, teknolojik araçların aşırı kullanımlarının ortaya koyduğu sonuçlardandır (Muslu ve Bolışık, 2009). Okul öncesi dönemde teknolojik araçların kullanımı, çocuklardaki oyunları ve dolayısıyla hareket düzeyini azaltabilmektedir (Sayan, 2016). Çocuğun teknoloji ile çok erken yaşta tanışması ve bu araçları aşırı kullanımı, öz düzenleme, diğer insanların duygu ve düşüncelerini 
anlama, dürtü kontrolü ve zihinsel esneklik gibi bilişsel işlevler üzerinde olumsuz etkilere yol alabilmektedir (Nathanson, Sharp, Aladé, Rasmussen ve Christy, 2013). Görüldügü üzere yaşamın ilk yıllarında çocukların teknolojik araçlarla mümkün olduğu kadar geç tanışması, bu araçlarla kısa ve eğitim amaçlı zaman geçirmesi önem taşımaktadır.

Teknolojik araçların yanı sıra bir yıldan fazla süredir dünya genelini birçok yönden olumsuz şekilde etkileyen bir diğer konu COVID 19 sürecidir. 2019 yılının son aylarında Çin'in Wuhan kentinde ortaya çıan ilk vakadan itibaren COVID 19, dünya geneline yayılmıştır (Dünya Sağlık Örgütü, 2020). Dünya Sağlık Örgütü (WHO) COVID 19'u pandemi olarak sinıflandırdıktan sonra hükümetler, tüm toplumu ilgilendirecek şekilde çeşitli tedbirler almışlardır. Sokağa çıkma yasakları ile birlikte kişilerin teknolojik araçları kullanma alışkanlıklarında da birtakım değişiklikler görülmüştür. Çin'in COVID 19 pandemisinden etkilenen bölgelerinden gelen ilk raporlar teknolojik araçların kullanımında önemli artışlar olduğunu ortaya koymuştur (Jiao vd., 2020). Aynı zamanda Wilde (2020) tüm yaş gruplarında rekor sayıda çevrimiçi video oyunlarına yönelme olduğunu belirtmiş̧ir.

Küresel boyutta sorun oluşturan COVID-19 pandemisi 2020 yılından itibaren Türkiye'de de görülmeye başlanmıştır. Pandemi önlemleri içerisinde eğitim kurumlarını, sinema salonlarının, tiyatroların, müzelerin ve spor tesislerinin geçici olarak kapatılması gibi birçok önlem alınmıştır. Yine bu kapsamda Türkiye'de 16 Mart 2020 'de okullarda yüz yüze eğitime ara verilmiş ve 23 Mart 2020'de uzaktan eğitime başlanmıştır. 3 Nisan 2020 tarihinden itibaren de aşamalı olarak 20 yaş altı ve 65 yaş üstü başta olmak üzere sokağa çıkma yasağı uygulamaları başlatılmıştır (Türkiye Cumhuriyeti İçişleri Bakanlığı, 2020). Bu karar kapsamında okul öncesi eğitime, öğretmenlerin önce kendi inisiyatifleriyle online ortamlardan etkinlik gönderilmesi ile başlanıp daha sonra Milli Eğitim Bakanlığı tarafından hazırlanan EBA (www.eba.gov.tr) portalı üzerinden devam edilmiştir. Sokağa çıkma yasağı önce belirli illerde, belirli yaş gruplarında ve belirli günlerde uygulanmış daha sonra yasak ülke genelini kapsamıştır. Pandemi süreci ve sokağa çıkma yasaklarından, toplumun her kesimi farklı şekillerde etkilenmiştir. Kısıtlamalar ve uzaktan eğitime geçme süreci, doğrudan ve dolaylı bir şekilde çocukların teknolojik araç kullanım sürelerinde değişikliklere yol açmıştır. COVID-19 süreciyle ilgili çalışmalar gittikçe artmaktadır. Örnek olarak bu süreçte, çocukların evde oyun oynamalarına ilişkin görüşlerin yer aldığı (Mart ve Kesicioğlu, 2020) ve çocukların psikolojik dayanıklılı̆̆ını artırma yollarının açıklandığı (Çaykuş ve Çaykuş, 2020) çalışmalar gerçekleştirilmiştir. Pandemi sürecinin uzamasından da kaynaklı olarak konu ile ilgili çalışmaların artırılması önem taşımaktadır. Böylece küçük çocukların süreçten kısa ve uzun süreli olarak nasıl etkilendikleri ortaya konulabilecektir. Bu nedenle, araştırmada COVID-19 pandemi sürecinin küçük çocukların teknolojik araç kullanım durumları çeşitli değişkenler açısından ele alınmıştır. Bu araştırmada küçük çocukların COVID 19 sürecinde teknolojik araç kullanımının çeşitli değiş̧kenler açısından incelenmesi 
amaçlanmıştır. Bu amaç doğrultusunda araştırmada, aşağıdaki alt problemlere yanıt aranmıştır.

\section{Alt Problemler}

1. COVID 19 sürecinde çocukların TV izleme ve bilgisayar kullanma süreleri değişiklik göstermiş midir?

2. COVID 19 sürecinde annelerin çocukların izledikleri TV yayınlarındaki ve kullandıkları bilgisayarlardaki içerikleri kontrol etme durumları nedir?

3. COVID 19 sürecinde çocukların TV izleme, bilgisayar kullanma süreleri ve içeriklerin kontrol edilmesi annelerin çalışma durumuna göre farklılaşmakta midir?

4. COVID 19 sürecinde çocukların TV izleme, bilgisayar kullanma süreleri ve içeriklerin kontrol edilmesi annelerin yaşına göre farklılaşmakta mıdır?

5. COVID 19 sürecinde çocukların TV izleme, bilgisayar kullanma süreleri ve içeriklerin kontrol edilmesi annelerin eğitim düzeyine göre farklılaşmakta midir?

6. COVID 19 sürecinde çocukların TV izleme ve bilgisayar kullanma düzeyleri çocuk sayısına göre farklılaşmakta mıdır?

\section{Yöntem}

Araştırma tarama modelinde kesitsel tarama türünde yapılmıştır. Sosyal bilimler kapsamında geniş gruplarla yürütülen, gruplarda yer alan kişilerin olay ya da olgularla ilgili görüş ve tutumlarının alındığı, bu olay ve olguların betimlenmeye çalışıldığı araştırmalar tarama araştırmalarıdır. Tarama modeline ait kesitsel tarama türünde özellikle geniş gruplar için evrenin tamamına ulaşmak mümkün olmadığında evren içerisinden gruplar seçilerek veriler toplanır (Tanrı̈ğgen, 2012).

\section{Çalışma Grubu}

Araştırmanın çalışma grubunu Bayburt ilinde okul öncesi eğitime devam eden 5 yaş grubundan 163 çocuk ve anneleri oluşturmaktadır. Araştırmaya çocukların 91'i $(\% 55,8)$ k1z, 72'si (\%44.2) erkektir. Araştırmaya katılan 163 annenin 35'i (\%21,5) 20-28; 97'si (\%59,5) 29-37 aralığındayken 31'i (\%19,02) 38 yaş ve üzerindedir. Annelerin 47'si $(\% 28,8)$ tek çocuk, 75'i $(\% 46,0)$ iki çocuk, 25'i $(\% 15,3)$ üç çocuk ve 16's1 (\%9,8) dört ve üzeri çocuk sahibidir. Annelerin 26'sı (\%16,0) ilkokul, 19'u (\%11,7) ortaokul, 46's1 $(\% 28,2)$ lise, 72'si $(\% 44,2)$ üniversite mezunu olup 62'si $(\% 38,0)$ çalışmakta, 101'i $(\% 62,0)$ ise çalışmamaktadır.

\section{Veri Toplama Araçları}

Verilerin toplanmasında araştırmacılar tarafından geliştirilen kapalı uçlu sorulardan oluşan yapılandırılmış anket formu kullanılmıştır. COVID-19 pandemisinde kısıtlamaların getirilmesinin ardından bu sürecin çocuklara etkileri ve sürecin yönetilmesi ile ilgili alanında uzman kişilerin sosyal medya kanalları 
üzerinden verdiği röportajlar izlenerek Online Anket Formu oluşturulmuştur (Güneş, 2020). Online Anket Formu, çocuklar ve anneler ile ilgili demografik bilgiler ile COVID-19 pandemisinde okul öncesi dönem çocukların teknolojik araç kullanımlarını belirlemek için hazırlanmış sorulardan oluşmaktadır. Demografik bilgileri; anne çalışma durumu, anne yaşı, anne eğitim düzeyi ve çocuk sayısı oluşturmaktadır. Teknolojik araç kullanımlarına yönelik ise annelere çocukların günlük TV izleme süreleri, bilgisayar kullanım süreleri sorulmuş saat şeklinde belirtmeleri istenen kapalı uçlu sorular sorulmuştur. Elde edilen süreler dakikaya çevrilmiştir. Toplam teknolojik araç kullanımı ise TV kullanım süresi ile bilgisayar kullanım süresi toplanarak elde edilmiştir. Teknolojik araç kullanım içeriklerini takip edip edememe durumları ise kapalı uçlu iki seçenekli soru ( $1=$ Kontrol edemedim, $2=$ Kontrol edebildim) ile toplanmıştır. Formla ilgili okul öncesi eğitim alanında çalışan üç akademisyenden uzman görüşü alınmıştır. Uzman görüşlerinden gelen düzenlemelerin ardından 5 kişi ile pilot çalışma yapılmışır. Pilot çalışmanın ardından veriler toplanmaya başlanmıştır.

\section{Verilerin Toplanmasi}

Online Anket Formu, Google Forms uygulamasında hazırlanmıştır. Online Anket Formu, sokağa çıkma kısıtlamalarının uygulanmaya başlamasının üzerinden belli bir zaman geçtikten, çocukların günlük rutinleri belirli düzeyde değiştikten sonra aileler tarafından 26 Haziran 2020 tarihinden itibaren doldurulmaya başlanmıştır. Formda Online Anket Formu Bayburt ili bağımsız anaokulu ve ilkokul müdürleri ve öğretmenleri aracıllğıyla ailelere iletilmiştir. İki yüz on iki kişi Online Anket Formu'nu doldurmuştur. Anneler dışındaki kişiler tarafından doldurulan formlar araştırma kapsamına alınmamıştır. Araştırmaya 163 anne ve çocuk dâhil edilmiştir. Veriler, Online Anket Formu'ndan Microsoft Excell programına aktarılmıştır. Çocukların günlük TV izleme süresi ve bilgisayar kullanma süresi dakika olarak hesaplandıktan sonra veriler SPSS 22.0 istatistik paket programına aktarılmıştır.

\section{Verilerin Analizi}

Verilerin normal dağılıp dağılmadıklarına bakmak amacıyla normallik testi yapılmıştır. Çalışma grubunun 50 kişiden fazla olması ve kullanılmış olan testlere ait normallik varsayımlarının incelenmesi için Kolmogorov Smirnov Testi yapılmışır (Büyüköztürk, Çokluk ve Köklü, 2016). Test sonucunda değişkenlerin çarpıklık ve basıklık değerlerinin $+1,5$ ve $-1,5$ aralığında olmadığı belirlenmiştir (Tabachnick, Fidell ve Ullman, 2007). Kolmogorov Smirnov Test sonuçlarına ve çarpıklık basıklık dağılımlarına göre verilerin normal dağılmadığı varsayılmıştır. Bu varsayımlara göre COVID 19 sürecinde çocukların TV izleme süresi, bilgisayar kullanma süresi, toplam teknolojik araç kullanım süresinin ve teknolojik araç kullanım içeriklerin kontrol edilmesinin annelerin çalışma durumuna göre farklılaşıp farklılaşmadığı Mann Whitney U testi ile, COVID 19 sürecinde çocukların TV izleme süresi, bilgisayar kullanma süresi, toplam teknolojik araç kullanım süresinin ve teknolojik araç kullanım içeriklerin kontrol edilmesinin annelerin yaşına, eğitim düzeyine ve çocuk sayısına 
göre farklılaşıp farklılaşmadığı Kruskal Wallis $H$ testi ile analiz edilmiştir. Kruskal Wallis $\mathrm{H}$ testi sonucunda çıan farklılıkların hangi gruplar arasında olduğunu belirlemek amacıyla gruplara Mann Whitney U testi uygulanmıştır.

\section{Bulgular}

Tablo 1. Çocukların günlük teknolojik araç kullanma süreleri

\begin{tabular}{lcccc}
\hline & \multicolumn{3}{c}{ Çocukların Günlük Teknolojik Araç Kullanma Süreleri } & \\
\cline { 2 - 5 } & Sayı(n) & En az & En çok & Ortalama \\
\hline $\begin{array}{l}\text { Toplam } \\
\begin{array}{l}\text { Teknolojik araç } \\
\text { kullanma süresi }\end{array}\end{array}$ & 163 & $10 \mathrm{dk}$ & $720 \mathrm{dk}$ & $197,6 \mathrm{dk}$ \\
\hline $\begin{array}{l}\text { TV izleme süresi } \\
\text { Bilgisayar } \\
\text { kullanma süresi }\end{array}$ & 163 & $15 \mathrm{dk}$ & $600 \mathrm{dk}$ & $115,5 \mathrm{dk}$ \\
\hline
\end{tabular}

Tablo 1 incelendiğinde, çocukların günlük TV izleme süresinin en az 15, en çok 600 ve ortalama 115 dakika; günlük bilgisayar kullanma süresinin en az 10, en çok 360 ve ortalama 82,1 dakika ve toplam günlük teknolojik araç süresinin en az 10, en çok 720 ve ortalama 197 dakika olduğu belirlenmiştir.

Tablo 2. COVID 19 sürecinde çocuklarn günlük TV izleme ve bilgisayar kullanma sürelerinin değişiklik gösterme durumları

\begin{tabular}{|c|c|c|c|}
\hline & $\begin{array}{l}\text { Çocukların TV izleme ve bilgisayar } \\
\text { kullanma sürelerindeki değişiklik }\end{array}$ & $\mathbf{N}$ & $\%$ \\
\hline \multirow[t]{4}{*}{ TV izleme } & TV izleme süreleri artmıştır. & 120 & 73,6 \\
\hline & TV izleme süreleri artmamıştır. & 43 & 26,4 \\
\hline & TV izleme süreleri azalmıştır. & 0 & 0.0 \\
\hline & Toplam & 163 & 100.0 \\
\hline \multirow{4}{*}{$\begin{array}{l}\text { Bilgisayar } \\
\text { kullanma }\end{array}$} & Bilgisayar kullanma süreleri artmıştır. & 122 & 74,8 \\
\hline & Bilgisayar kullanma süreleri artmamıştır. & 41 & 25,2 \\
\hline & Bilgisayar kullanma süreleri azalmıştır & 0 & 0.0 \\
\hline & Toplam & 163 & 100.0 \\
\hline
\end{tabular}


Tablo 2'ye göre çocukların 120'sinin $(\% 73,6)$ günlük TV izleme süresi artmış, 43'ünün $(\% 26,4)$ TV izleme süresinde artış görülmemiştir. Yüz yirmi iki $(\% 74,8)$ çocuğun bilgisayar kullanma süresi artmış, 41 (\%25,2) çocuğun bilgisayar kullanma süresi artmamıştır. Bulgulara göre araştırmada, TV izleme ve bilgisayar kullanma süreleri azalan çocuk bulunmamaktadır.

Tablo 3. Çocukların izledikleri TV ve kullandıkları bilgisayar içeriklerinin kontrol edilme durumları

\begin{tabular}{|c|c|c|c|c|}
\hline & $\begin{array}{l}\text { Çocukların izledikleri TV ve kulla } \\
\text { bilgisayar içeriklerinin kontrol } \\
\text { durumları }\end{array}$ & $\begin{array}{l}\text { adıkları } \\
\text { edilme }\end{array}$ & $\mathbf{N}$ & $\%$ \\
\hline \multirow[t]{3}{*}{ TV izleme } & TV içerikleri kontrol edilebilmiştir. & & 122 & 74,8 \\
\hline & TV içeriklerini kontrol edilememiştir. & & 41 & 25,2 \\
\hline & Toplam & & 163 & 100,0 \\
\hline \multirow[t]{3}{*}{$\begin{array}{l}\text { Bilgisayar } \\
\text { kullanma }\end{array}$} & $\begin{array}{l}\text { Bilgisayar kullanma içerikleri } \\
\text { edilebilmiştir. }\end{array}$ & kontrol & 111 & 68,1 \\
\hline & $\begin{array}{l}\text { Bilgisayar kullanma içerikleri } \\
\text { edilememiştir. }\end{array}$ & kontrol & 52 & 31,9 \\
\hline & Toplam & & 163 & 100,0 \\
\hline
\end{tabular}

Tablo 3'de, 122 çocuğun $(\% 74,8)$ izlediği TV programlarının içerikleri anneleri tarafından kontrol edilmiş, $41^{\prime}$ inin $(\% 25,2)$ izlediği TV programlarının içeriği anneler tarafından kontrol edilememiştir. Çocukların 111'inin (\%68,1) kullandıkları bilgisayarlardaki içerikler anneleri tarafından kontrol edilebilmiş, 52'sinin $(\% 31,9)$ kullandıkları bilgisayarlardaki içerikler kontrol edilememiştir.

Tablo 4. COVID 19 sürecinde çocukların TV izleme, bilgisayar kullanma süreleri ve içeriklerin kontrol edilmesinin anne çalş̧ma durumuna göre Mann Whitney U testi sonuçları

\begin{tabular}{lllllll}
\hline & $\begin{array}{l}\text { Anne } \\
\text { Çalışma } \\
\text { Durumu }\end{array}$ & N & S.O. & S.T. & U & p \\
\hline TV izleme süresi & Çalışıyor & 62 & 64,35 & 3989,50 & & \\
\cline { 2 - 7 } & Çalışmiyor & 101 & 92,84 & 9376,50 & 2036,500 & \multirow{2}{*}{$000^{*}$} \\
\hline & Toplam & 163 & & & & \\
\hline & Çalışıyor & 62 & 76,35 & 4733,50 & & \\
\hline
\end{tabular}




\begin{tabular}{|c|c|c|c|c|c|c|}
\hline \multirow{2}{*}{$\begin{array}{l}\text { Bilgisayar } \\
\text { süresi }\end{array}$} & Çalışmıyor & 101 & 85,47 & 8632,50 & 2780,500 & , 145 \\
\hline & Toplam & 163 & & & & \\
\hline \multirow{3}{*}{$\begin{array}{l}\text { Toplam Teknolojik araç } \\
\text { kullanma süresi }\end{array}$} & Çalışıyor & 62 & 73,03 & 4528,00 & & \\
\hline & Çalışmıyor & 101 & 87,50 & 8838,00 & 2575,000 &, $023^{*}$ \\
\hline & Toplam & 163 & & & & \\
\hline \multirow{3}{*}{$\begin{array}{l}\text { Teknolojik araçların } \\
\text { kullanım içeriklerinin } \\
\text { kontrol edilmesi }\end{array}$} & Çalışıyor & 62 & 91,93 & 5699,50 & & \\
\hline & Çalışmıyor & 101 & 75,91 & 7666,50 & 2515,500 &, $018^{*}$ \\
\hline & Toplam & 163 & & & & \\
\hline
\end{tabular}

${ }^{*} \mathrm{p}<.05$

Tablo 4'de, çocukların TV izleme süresinin anne çalışma durumuna göre istatistiksel açıdan anlamlı düzeyde farklılaştığı belirlenmiştir ( $U=2036,500, p<.05)$. Çocukların TV izleme süreleri, çalışan annelerin lehine anlamlı düzeyde farklılaşmaktadır. Çocukların bilgisayar kullanma süresinin anne çalışma durumuna göre farklılaşmadığ 1 belirlenmiştir ( $U=2780,500, p>.05)$. Çocukların toplam teknolojik araç kullanım süresinin anne çalışma durumuna göre istatistiksel açıdan anlamlı düzeyde farklılaştığı ortaya konulmuştur ( $\mathrm{U}=2575,000$, $\mathrm{p}<.05)$. Çocukların toplam teknolojik araç kullanma süresi çalışan annelerin lehine farklılaşmaktadır. Ayrıca teknolojik araçların kullanım içeriklerinin kontrol edilmesinin anne çalışma durumuna göre istatistiksel açıdan anlamlı düzeyde farklılaştığı görülmektedir ( $\mathrm{U}=2515,500, \mathrm{p}<.05)$. Teknolojik araçların kullanım içeriklerinin kontrol edilmesinin çalışan annelerin lehine anlamlı düzeyde farklılaştığı belirlenmiştir.

Tablo 5. COVID 19 sürecinde çocukların TV izleme, bilgisayar kullanma süreleri ve içeriklerin kontrol edilmesinin anne yaşına göre Kruskal Wallis H testi sonuçları

\begin{tabular}{|c|c|c|c|c|c|c|c|}
\hline & $\begin{array}{l}\text { Anne } \\
\text { Yaşi }\end{array}$ & $\mathbf{n}$ & $\overline{\mathrm{X}}$ & sd & $X^{2}$ & $\mathbf{p}$ & Anlamlı Fark \\
\hline \multirow[t]{4}{*}{ TV izleme süresi. } & $20-28$ & 35 & 81,59 & & & & \multirow{4}{*}{$\begin{array}{l}20-28 \text { yaş ile } 38 \text { ve } \\
\text { üstü } \\
29-37 \text { ile } 38 \text { ve üstü }\end{array}$} \\
\hline & $29-37$ & 97 & 75,61 & & & & \\
\hline & 38 ve üstü & 31 & 102,47 & 2 & 10,152 &, $006^{*}$ & \\
\hline & Toplam & 163 & & & & & \\
\hline \multirow{2}{*}{$\begin{array}{l}\text { Bilgisayar kullanma } \\
\text { süresi }\end{array}$} & $20-28$ & 35 & 84,27 & & & & \\
\hline & $29-37$ & 97 & 80,05 & & & & \\
\hline
\end{tabular}




\begin{tabular}{|c|c|c|c|c|c|c|c|}
\hline & 38 ve üstü & 31 & 85,55 & 2 & ,624 & ,732 & \\
\hline & Toplam & 163 & & & & & \\
\hline \multirow{4}{*}{$\begin{array}{l}\text { Toplam } \\
\text { araç } \\
\text { süresi }\end{array}$} & $20-28$ & 35 & 77,61 & & & & \\
\hline & $29-37$ & 97 & 79,73 & & & & \\
\hline & 38 ve üstü & 31 & 94,06 & 2 & 3,658 & 161 & \\
\hline & Toplam & 163 & & & & & \\
\hline \multirow{4}{*}{$\begin{array}{l}\text { Teknolojik araçların } \\
\text { kullanma } \\
\text { içeriklerinin kontrol } \\
\text { edilmesi }\end{array}$} & $20-28$ & 35 & 88,77 & & & & \multirow{4}{*}{$\begin{array}{l}\text { 20-28 yaş ile } 38 \text { ve } \\
\text { üstü } \\
\text { 29-37 ile } 38 \text { ve üstü }\end{array}$} \\
\hline & $29-37$ & 97 & 85,64 & & & & \\
\hline & 38 ve üstü & 31 & 62,95 & 2 & 7,980 &, $018^{*}$ & \\
\hline & Toplam & 163 & & & & & \\
\hline
\end{tabular}

${ }^{*} \mathrm{p}<.05$

Tablo 5'de, çocukların TV izleme süresinin anne yaşına göre istatistiksel açıdan anlamlı düzeyde farklılaştığ bulunmuştur $\left[X^{2}(2)=10,152, p<.05\right]$. Sira ortalamalarına göre 20-28 yaş grubundaki annelerle 38 ve üstü yaş grubu anneler karşılaştırıldığında 20-28 yaş grubundaki annelerin; 29-37 yaş grubu ile 38 ve üstü yaş grubu anneler karşılaştırıldığında, 29-37 yaş grubundaki annelerin lehine çocukların TV izleme süreleri farklılaşmıştır. Çocukların bilgisayar kullanma süresinin anne yaşına göre farklılaşmadığ belirlenmiştir $\left[X^{2}(2)=.624, p>.05\right]$. Çocukların toplam teknolojik araç kullanma süresinin anne yaşına göre farklılık göstermediği ortaya konulmuştur $\left[X^{2}(2)\right.$ $=3,658, p>$.05]. Teknolojik araçların kullanma içeriklerinin kontrol edilmesinin anne yaşına göre farklılık gösterdiği belirlenmiştir $\left[X^{2}(2)=7,980, p<.05\right]$. Sıra ortalamalarına göre 20-28 yaş grubu ile 38 ve üstü yaş grubu karşılaştırıldığında, 20-28 yaş grubu annelerin; 29-37 yaş grubu ile 38 ve üstü yaş grubu anneler karşılaştırıldı̆̆ında ise 29 ve 37 yaş grubundaki annelerin lehine teknolojik araçların kullanma içeriklerinin kontrol edilmesi anlamlı düzeyde farklılaşmıştır.

Tablo 6. COVID 19 sürecinde çocukların TV izleme, bilgisayar kullanma süreleri ve içeriklerin kontrol edilmesinin anne eğitim düzeyine göre Kruskal Wallis H testi sonuçları

\begin{tabular}{|c|c|c|c|c|c|c|c|}
\hline & $\begin{array}{l}\text { Anne } \\
\text { Eğitim } \\
\text { Düzeyi }\end{array}$ & $\mathbf{n}$ & $\overline{\mathrm{X}}$ & sd & $X^{2}$ & $\mathbf{p}$ & Anlamlı Fark \\
\hline \multirow[t]{3}{*}{ TV izleme süresi } & İlkokul & 26 & 98,42 & & & & \multirow{3}{*}{$\begin{array}{l}\text { İlkokul-Üniversite, } \\
\text { Ortaokul-Üniversite, } \\
\text { Lise-Üniversite }\end{array}$} \\
\hline & Ortaokul & 19 & 93,47 & & & & \\
\hline & Lise & 46 & 89,84 & 3 & 15,795 &, $001^{*}$ & \\
\hline
\end{tabular}




\begin{tabular}{|c|c|c|c|c|c|c|c|}
\hline & Üniversite & 72 & 68,03 & & & & \\
\hline & Toplam & 163 & & & & & \\
\hline \multirow{5}{*}{$\begin{array}{l}\text { Bilgisayar } \\
\text { kullanma süresi }\end{array}$} & İlkokul & 26 & 79,08 & & & & \multirow[t]{5}{*}{ Lise-Üniversite } \\
\hline & Ortaokul & 19 & 88,32 & & & & \\
\hline & Lise & 46 & 94,75 & 3 & 9,275 &, $026^{*}$ & \\
\hline & Üniversite & 72 & 73,24 & & & & \\
\hline & Toplam & 163 & & & & & \\
\hline \multirow{5}{*}{$\begin{array}{lr}\text { Toplam } & \text { Teknolojik } \\
\text { araç } & \text { kullanma } \\
\text { süresi } & \end{array}$} & İlkokul & 26 & 89,62 & & & & \multirow{5}{*}{$\begin{array}{l}\text { İlkokul-Üniversite, } \\
\text { Ortaokul-Üniversite, } \\
\text { Lise-Üniversite }\end{array}$} \\
\hline & Ortaokul & 19 & 90,61 & & & & \\
\hline & Lise & 46 & 94,52 & 3 & 14,367 &, $002^{*}$ & \\
\hline & Üniversite & 72 & 68,98 & & & & \\
\hline & Toplam & 163 & & & & & \\
\hline \multirow{5}{*}{$\begin{array}{l}\text { Teknolojik } \\
\text { araçların kullanma } \\
\text { içeriklerinin } \\
\text { kontrol edilmesi }\end{array}$} & İlkokul & 26 & 79,88 & & & & \multirow{5}{*}{$\begin{array}{l}\text { Ortaokul-Üniversite, } \\
\text { Lise-Üniversite }\end{array}$} \\
\hline & Ortaokul & 19 & 56,13 & & & & \\
\hline & Lise & 46 & 73,33 & 3 & 16,200 &, $001^{*}$ & \\
\hline & Üniversite & 72 & 95,13 & & & & \\
\hline & Toplam & 163 & & & & & \\
\hline
\end{tabular}

${ }^{*} \mathrm{p}<.05$

Tablo 6'ya göre çocukların TV izleme süresinin anne eğitim düzeyine göre istatistiksel açıdan anlamlı düzeyde farklılaştığı ortaya konulmuştur $\left[X^{2}(3)=15,795\right.$, $\mathrm{p}<.05]$. Üniversite ile ilkokul; üniversite ile ortaokul ve üniversite ile lise eğitim düzeyi karşılaştırıldığında üniversite mezunlarının lehine çocukların TV izleme süreleri anlamlı şekilde farklılaşmaktadır. Çocukların bilgisayar kullanma süresi ile anne eğitim düzeyi arasında anlamlı farklılık bulunmuştur [ $\left.X^{2}(3)=9,275, p<.05\right]$. Üniversite ile lise karşılaştırıldığında; üniversite mezunu annelerin lehine çocukların bilgisayar kullanma süresi farklılaşmaktadır. Çocukların toplam teknolojik araç kullanma süresi ile anne eğitim düzeyi arasında anlamlı farklılık bulunmuştur $\left[X^{2}(3)=14,367, \mathrm{p}<.05\right]$. Üniversite ile ilkokul; üniversite ile ortaokul ve üniversite ile lise karşılaştırıldı ̆̆ında; üniversite mezunu annelerin lehine çocukların toplam teknolojik araç kullanma süreleri anlamlı düzeyde farklılaşmaktadır. Teknolojik araçların kullanım içeriklerinin kontrol edilmesi ile anne eğitim düzeyi arasında anlamlı farklılaşma bulunmuştur [ $X^{2}$ (3) $=16,200, p<.05]$. Üniversite ile ortaokul; üniversite ile lise karşılaştırıldı̆̆ında, 
üniversite mezunu annelerin lehine teknolojik araçların içeriklerinin kontrol edilmesi anlamlı düzeyde farklılaşmaktadır.

Tablo 7. COVID 19 sürecinde çocukların TV izleme, bilgisayar kullanma süreleri ve içeriklerin kontrol edilmesinin çocuk sayısına göre Kruskal Wallis H testi sonuçları

\begin{tabular}{|c|c|c|c|c|c|c|c|}
\hline & Çocuk Sayısı & $\mathbf{n}$ & $\overline{\mathrm{X}}$ & s.d & $X^{2}$ & $\mathbf{p}$ & Anlamlı Fark \\
\hline \multirow[t]{5}{*}{ TV izleme süresi } & Tek Çocuk & 47 & 62,81 & & & & \multirow{5}{*}{$\begin{array}{l}\text { Tek çocuk-iki çocuk, } \\
\text { tek çocuk-dört üstü } \\
\text { çocuk, } \\
\text { üç çocuk-dört çocuk }\end{array}$} \\
\hline & 2 Çocuk & 75 & 90,90 & & & & \\
\hline & 3 Çocuk & 25 & 74,60 & & & & \\
\hline & 4 ve üstü Çocuk & 16 & 108,22 & 3 & 21,326 &, $000^{*}$ & \\
\hline & Toplam & 163 & & & & & \\
\hline \multirow{5}{*}{$\begin{array}{l}\text { Bilgisayar } \\
\text { kullanma süresi }\end{array}$} & Tek Çocuk & 47 & 67,87 & & & & \multirow{5}{*}{$\begin{array}{l}\text { Tek çocuk-iki çocuk, } \\
\text { tek çocuk-dört ve } \\
\text { üstü çocuk }\end{array}$} \\
\hline & 2 Çocuk & 75 & 94,21 & & & & \\
\hline & 3 Çocuk & 25 & 70,30 & & & & \\
\hline & 4 ve üstü Çocuk & 16 & 84,56 & 3 & 15,978 &, $001^{*}$ & \\
\hline & Toplam & 163 & & & & & \\
\hline \multirow{5}{*}{$\begin{array}{l}\text { Toplam } \\
\text { Teknolojik araç } \\
\text { kullanma süresi }\end{array}$} & Tek Çocuk & 47 & 62,40 & & & & \multirow{5}{*}{$\begin{array}{l}\text { Tek çocuk-iki çocuk, } \\
\text { tek çocuk-üç çocuk, } \\
\text { tek çocuk-dört ve } \\
\text { üstü çocuk }\end{array}$} \\
\hline & 2 Çocuk & 75 & 93,29 & & & & \\
\hline & 3 Çocuk & 25 & 81,34 & & & & \\
\hline & 4 ve üstü Çocuk & 16 & 87,66 & 3 & 18,099 &, $000^{*}$ & \\
\hline & Toplam & 163 & & & & & \\
\hline \multirow{5}{*}{$\begin{array}{l}\text { Teknolojik } \\
\text { araçların } \\
\text { kullanma } \\
\text { içeriklerinin } \\
\text { kontrol edilmesi }\end{array}$} & Tek Çocuk & 47 & 91,09 & & & & \multirow{5}{*}{$\begin{array}{l}\text { Tek çocuk-dört ve } \\
\text { üstü çocuk, } \\
\text { iki çocuk-dört ve } \\
\text { üstü çocuk, } \\
\text { üç çocuk-dört çocuk }\end{array}$} \\
\hline & 2 Çocuk & 75 & 83,63 & & & & \\
\hline & 3 Çocuk & 25 & 91,30 & & & & \\
\hline & 4 ve üstü Çocuk & 16 & 33,13 & 3 & 25,091 &, $000^{*}$ & \\
\hline & Toplam & 163 & & & & & \\
\hline
\end{tabular}

${ }^{*} \mathrm{p}<.05$

Tablo 7 incelendiğinde, çocukların TV izleme süresi ile annelerin çocuk sayısı arasında anlamlı farklılık bulunmuştur $\left[X^{2}(3)=21,326, p<.05\right]$. Tek çocuk ile iki çocuk, 
tek çocuk ile dört ve üzeri çocuk karşılaştırıldığında, tek çocuğu olan annelerin lehine; üç çocuk ile dört ve üzeri çocuk karşılaştırıldığında üç çocuk sahibi annelerin lehine çocukların TV izleme süreleri anlamlı düzeyde farklılaşmaktadır. Çocukların bilgisayar kullanma süresi ile annelerin çocuk sayısı arasında anlamlı farklılık bulunmuştur $\left[X^{2}(3)=15,978, p<.05\right]$. Tek çocuk sahibi annelerle iki çocuk sahibi anneler karşılaştırıldığında, tek çocuk sahibi annelerin lehine, iki çocuk sahibi annelerle dört ve üstü çocuk sahibi anneler karşılaştırıldığında iki çocuk sahibi annelerin lehine çocukların bilgisayar kullanma süresi anlamlı düzeyde farklılaşmaktadır. Çocukların toplam teknolojik araç kullanma süresi ile annelerin çocuk sayısı arasında anlamlı farklılık bulunmuştur $\left[X^{2}(3)=18,099, \mathrm{p}<.05\right]$. Tek çocuk sahibi annelerle iki çocuk sahibi anneler, tek çocuk sahibi annelerle üç çocuk sahibi anneler ve tek çocuk sahibi annelerle dört çocuk sahibi anneler karşılaştırıldığında, tek çocuk sahibi annelerin lehine çocukların toplam teknolojik araç kullanma süresi anlamlı düzeyde farklılaşmaktadır. Teknolojik araçların kullanma içeriklerinin kontrol edilmesi ile annelerin çocuk sayısı arasında anlamlı bir farklılık bulunmuştur $\left[X^{2}(3)=\right.$ 25,091, p<.05]. Dört çocuk ve üstü ile tek çocuk sahibi, dört çocuk ve üstü ile iki çocuk sahibi, dört çocuk ve üstü ile 3 çocuk sahibi anneler karşılaştırıldığında, dört çocuk ve üstü çocuk sahibi annelerin aleyhinde teknolojik araçların kullanım içeriklerinin kontrol edilmesi anlamlı düzeyde farklılaşmaktadır.

\section{Sonuç ve Tartışma}

Küçük çocukların, COVID 19 sürecinde teknolojik araç kullanım düzeylerinin çeşitli değişkenlere göre incelendiği bu çalışmada, çocukların bir gün içerisinde yaklaşık 2 saat televizyon izledikleri ve 1 saati aşan sürelerde bilgisayar kullandıkları, toplamda günde ortalama 3 saat teknolojik araçlarla zaman geçirdikleri belirlenmiştir. Araştırmaya katılan annelerin çoğunluğu çocuklarının günlük teknolojik araç kullanım sürelerinin arttığını ifade etmiştir. Çalışma grubundaki çocukların teknolojik araç kullanım sürelerinin azaldığına yönelik bulgu elde edilmemiştir. Dolayısıyla COVID 19 süreciyle birlikte çok uzun süreler evde zaman geçirmek durumunda kalan küçük çocukların televizyon ve bilgisayarla öncekine göre daha çok zaman geçirdiği söylenebilir. COVID 19 süreci gerek çocuklar gerek anne-babalar açısından farklı zorlukları beraberinde getirmiştir. Var olan rutinlerinin değişmesi ve yeni rutinlere (sokağa çıkmama, sosyal ortamdan uzak kalma gibi) alışma süreci ailelerdeki stresi arttırmıştır (American Psychological Association [APA], 2020). Lee ve meslektaşlarının (2020), COVID 19 sürecinde, 0-12 yaş arasında çocuğu olan 405 annebaba ile yaptığı çalışma sonucunda, anne-babaların çoğunluğunun zamanlarının önemli bir bölümünü eğitim, bakım gibi çocuklarla ilgili işlerle geçirdikleri ve bir bölümünün kaygı, depresyon gibi psikolojik sorunlar yaşadıkları belirlenmiştir. Güngör ve meslektaşları (2020), pandemi süreci öncesinde gerçekleştirdikleri çalışmaya istinaden Türkiye'de ve Dünya genelinde çocukların teknolojik araç kullanım sürelerinin arttığına dikkat çekmişlerdir. Medrano ve meslektaşlarının (2021) COVID 19 sürecinde 291 çocuk ile yaptığı araştırma sonucunda fiziksel etkinliğe 
ayrılan zamanın azaldığını, ekran karşısında geçen sürenin arttığını belirlemişlerdir. Goagoses, Winschiers-Theophilus ve Chamunorwa (2020), COVID 19 sürecinin çocukların teknolojik araçlarla etkileşimlerini arttırmanın yanı sıra akran ilişkilerine ve sosyal duygusal öğrenme süreçlerine zarar verebileceğini ifade etmiştir. Göker ve Turan (2020), pandemi sürecinde her yaşta insanın problemli teknoloji kullanımı açısından risk altında olduğunu ve özellikle çocukların davranışlarının izlenmesinin önemli olduğunu belirtmişlerdir. Alan yazındaki çalışmalar ile bu araştırmanın bulguları çocukların teknolojik araçlarla geçirdikleri sürenin arttı̆̆ı yönünde paralellik göstermektedir. Bu bağlamda, COVID 19 süreciyle yaşam tarzındaki zorunlu değişikliklerin teknolojik araçları kullanma sürelerini olumsuz yönde etkileyebildiği söylenebilir.

Araştırmaya katılan annelerin çoğunluğu, okul öncesi dönem çocuklarının zaman geçirdiği teknolojik araçların içeriklerini kontrol edemediklerini ifade etmişlerdir. Zehir ve meslektaşları (2019) tarafından 4-6 yaş grubundan çocukları olan 280 anne-baba ile gerçekleştirilen çalışmanın sonucunda, ailelerin çocuklarının teknolojik araçlarla oynadıkları oyunları, ziyaret edilen internet sitelerini takip ettiği, süre kısıtlaması getirdiği belirlenmiştir. Bu çalışmanın bulguları, Zehir ve meslektaşlarının (2019) bulguları ile örtüşmemektedir. Annelerin çoğunluğunun çalışmamasına rağmen çocuklarının teknolojik araçları kullanırken neleri izlediklerini ya da neler yaptıklarını kontrol edememeleri dikkat çekmektedir. Bu araştırmadaki annelerin çoğunluğunun iki ve daha fazla çocuk sahibi olmasının, bu durumu açıklayabilecek unsurlardan biri olduğu düşünülebilir. Ev ile ilgili işler ile çocukların eğitim dâhil birçok sorumluluğu içerisinde annelerin, okul öncesi dönem çocuklarının teknolojik araçlarla neler yaptıklarına odaklanamadıklarını düşünülebilir. Ayrıca, annelerin çocuklarının teknolojik araçlarla neler yaptıklarını kontrol edememesi, COVID 19 sürecinin getirdiği yeni yaşam düzenine uyum süreciyle de açıklanabilir. Çalışmanın bulgularına göre çalışan annelerin, çocukların TV izleme süresini ve teknolojik araçlarla zaman geçirmeyle ilgili toplam süreyi, çalışmayan annelere göre daha çok kontrol edebildiği görülmektedir. Bununla birlikte çocukların bilgisayar kullanma süresinin annelerin çalışma durumuna göre farklılaşmadığı ortaya konulmuştur.

Çocukların tv izleme süresi ile teknolojik araçların kullanım içeriklerinin kontrol edilmesinde anne yaşı açısından farklılıklar belirlenmiştir. En yüksek tv izleme ortalamaları 38 yaş ve üstü annelerin çocuklarına ait iken en düşük tv izleme ortalaması 29-37 yaş arası annelerin çocuklarına aittir. Auxier ve meslektaşları (2020), çocuk yetiştirme ile ilgili anne-babalarla gerçekleştirdikleri bir çalışmada, yaşı büyük olan anne-babaların ebeveynliği küçük yaş gruplarına göre zor bulduklarını ortaya koymuşlardır. Yaşı büyük olan ebeveynlerden bazıları, çocuk yetiştirmenin zorluğunu teknolojinin kullanım oranındaki artışa ve teknolojinin hızlı ve sürekli değişmesine bağlamıştır.

Annelerin eğitim düzeylerinin çocuklarının teknolojik araçlarla ne kadar süre geçirdikleri ve içeriklerin kontrolünde farklılıklar oluşturabildiği görülmektedir. 
Üniversite mezunu annelerin çocuklarının en az TV izleme, bilgisayar kullanım ve teknolojik araç kullanımdaki toplam sürelere sahip oldukları görülmektedir. Ayrıca üniversite mezunu annelerin teknolojik araçların içeriklerini diğer annelere göre daha çok kontrol ettikleri belirlenmiştir. Bulgular, annenin eğitim düzeyinin çocuğun teknolojik araç kullanımındaki etkisini ortaya koyması açısından ilginçtir. Nitekim Özcan (2018) tarafından yapılan bir çalışmada, Amasya'da yaşayan 4-6 yaş arası 298 çocuğun dâhil edildiği çalışmada, anne-babaların eğitim düzeyi yükseldikçe teknolojik araçların olumsuz etkilerini daha çok ifade ettikleri belirtilmiştir. Dolayısıyla ebeveynlerin eğitim düzeylerinin, çocuklarının teknolojik araç kullanımına olumlu yönde etki edebildiği söylenebilir.

Çocuk sayısı açısından 4 ve üstü çocuğu olan ailelerdeki okul öncesi dönem çocuklarının en çok TV izleyen grup, tek çocukların da en az izleyen grup olduğu ortaya konulmuştur. Bunun yanı sıra iki çocuklu ailelerdeki okul öncesi dönem çocuklarının en çok bilgisayarda zaman geçiren grup olduğu, tek çocukların da en az vakit geçiren grup olduğu belirlenmiştir. Toplam teknolojik araç kullanım süresi açısından en az zaman geçiren grup tek çocuklar iken çok zaman geçiren çocuklar 2 çocuklu ailelerde yer almıştır. İçeriklerin kontrol edilmesinde 4 ve üstü çocuğu olan ailelerin içeriği en az kontrol edebilen grup, tek çocuğu olan ailelerin de içeriğin en çok kontrol edildiği grup olduğu belirlenmiştir. Bu sonuç doğrultusunda tek çocuğu olan ailelerin, dikkatlerini ilgilerini tek bir kaynağa yönlendirmelerinden kaynaklı olarak çocuğu teknolojik araçlar dişında farklı etkinliklere, uyaranlara yönlendirebilecekleri düşünülebilir. Paralel şekilde, birden fazla çocuğu olan ailelerde de ilgi ve dikkatin çok sayıda kaynağa aktarılması sonucunda, çocukların teknolojik araçlarla ne kadar süre vakit geçirdiklerine ve neler yaptıklarına daha az dikkat edilmiş olabilir. Başaran ve Aksoy (2020), COVID 19 sürecinde 26 anne-baba ile yaptıkları görüşme sonucunda, anne-babaların çocuklardaki teknoloji bağımlılığını pandemi sürecindeki bir problem durumu olarak ifade etmişlerdir. Çocuk sayısının yanı sıra aileler COVID 19 sürecinin getirdiği bir takım sorunlar (sağlık sorunları, ekonomik sorunlar, aile üyelerinden ya da yakınlardan birinin kaybı vb.) nedeniyle de çocukların teknolojik araç kullanımına yönelik pedagojik bir bakış açısı sunamamış olabilirler. COVID 19, Dünya genelinde her yaşta insanı kısa ve uzun süreli olarak farklı şekillerde olumsuz etkilemiştir (Nicola ve diğg., 2020).

Konu ile ilgili olarak teknolojik araçların belli bir süreyle sınırlı kalınarak bilinçli bir şekilde kullanılmasının çocukların gelişimini olumlu yönde etkileyebildiğini de vurgulamak önem taşımaktadır. COVID 19 sürecinde de teknoloji kullanımının bilinçli olması gereklidir (Goldschmidt, 2020). Özellikle okul öncesi dönem çocuklarının yetişkin rehberliğinde belli sürelerde, eğitim amaçlı kullanılması, yeni bilgilerin öğrenilmesi ve/veya öğrenilenlerin pekiştirilmesi açısından da etkili olabilecektir.

$\mathrm{Bu}$ araştırma doğrultusunda, COVID 19 sürecinde ailelerin teknolojik araçların bilinçli bir şekilde kullanımına yönelik bilgilendirilmeleri gerektiği ortaya çıkmaktadır. Okul öncesi eğitimi öğretmenleri, aileleri teknolojik araçların önemi, 
etkileri konularında bilgilendirebilirler. Ayrıca ailelere çocuklarıyla evde yapabilecekleri etkinlikler, çalışmalarla ilgili bilgi verilmeli, aile katılımı etkinlikleri ile bu konuda deneyim kazanmaları sağlanmalıdır. Konu ile ilgili çalışmalarda, babaların da COVID 19 sürecinde çocuklarla iletişimi, çocukların teknolojik araçları kullanmalarındaki rolleri, konu ile ilgili görüşleri gibi konular incelenebilir. Anne ve babaların COVID 19 sürecinde çocuk üzerindeki ortak etkisi de ele alınabilir. Dünya ve Türkiye için olağanüstü bir dönem olan pandemi sürecinin çocuklar, anne-babalar üzerindeki çeşitli açılardan etkileri değerlendirilebilir.

\section{Etik Beyan}

“Küçük Çocukların COVID 19 Sürecinde Teknolojik Araç Kullanımlarının Çeşitli Değişkenler Açısından İncelenmesi" başlıklı çalışmanın yazım sürecinde bilimsel, etik ve alıntı kurallarına uyulmuş; toplanan veriler üzerinde herhangi bir tahrifat yapılmamış ve bu çalışma herhangi başka bir akademik yayın ortamına değerlendirme için gönderilmemiştir.

\section{Kaynaklar}

American Psychological Association [APA] (2020). Stress in America 2020: Stress in the time of COVID-19 (Vol. 1). Washington, DC: American Psychological Association.

American Academy of Pediatrics. (2016). American academy of pediatrics announces new recommendations for children's media use. Erişim adresi https://www.aap.org/enus/aboutthe-aap/aap-press-room/Pages/American-Academy-of-Pediatrics-AnnouncesNewRecommendations-for-Childrens-Media-Use.aspx

Apaydın, Ç. \& Kaya, F. (2020). An analysıs of the preschool teachers' views on alpha generation. European Journal of Education Studies, 6(11), 123-141. Doi: 10.5281/zenodo.3627158

Auxier, B., Anderson, M., Perrin, A. \& Turner, E. (2020). 4. Parents' attitudes - and experiences - related to digital technology. Parenting Children in the age of screens. Pew Research Center Internet \& Technology, July, 28, https://www.pewresearch.org/internet/2020/07/28/parents-attitudes-and-experiencesrelated-to-digital-technology/

Başaran, M., \& Aksoy, A.B. (2020). Anne-babaların korona-virüs (COVID-19) salgını sürecinde aile yaşantılarına ilişkin görüşleri. Uluslararası Sosyal Araştırmalar Dergisi, 13(71), 668-678.

Büyüköztürk, Ş., Çokluk, Ö. \& Köklü, N. (2016). Sosyal bilimler için istatistik (18. Baskı). Ankara: Pegem Akademi.

Canbek, G. \& Sağıroğlu, G. (2007). Çocukların ve gençlerin bilgisayar ve internet güvenliği. Politeknik Dergisi, 10(1), 33-39.

Common Sense Media. (2017). The common sense census: Media use by kids age zero to eight. San Francisco, CA: Author.

Çaykuş, E. T., \& Çaykuş, T. M. (2020). Covıd-19 Pandemi Sürecinde Çocukların Psikolojik Dayanıklılığını Güçlendirme Yolları: Ailelere, Öğretmenlere Ve Ruh Sağlığı Uzmanlarına Öneriler. Avrasya Sosyal Ve Ekonomi Araştırmaları Dergisi, 7(5), 95-113. 
Çebi, A. \& Özdemir, T.B. (2019). The role of digital nativity and digital citizenship in predicting high school students' online information searching strategies. Education and Science, 44(200), 47-57.http://dx.doi.org/10.15390/EB.2019.8379

Goagoses, N., Winschiers-Theophilus, H., ve Chamunorwa, M. B. (2020). The (potential) role of technology for young children's social-emotional learning: during and beyond the covid19 pandemic. Digit. Gov.: Res. Pract., 2(1), https://doi.org/10.1145/3429986.

Goldschmidt, K. (2020). The COVID-19 Pandemic: Technology use to support the wellbeing of children. Journal of Pediatric Nursing, 53, 88-90. https://doi.org/10.1016/j.pedn.2020.04.013

Göker M. E. ve Turan Ş. (2020). COVID-19 Pandemisi Sürecinde Problemli Teknoloji Kullanımı. ESTÜDAM Halk Să̆ğı̆ı Dergisi. 5(COVID-19 Özel Sayısı), 108-14.

Güngör, H., Gülay Ogelman, H., Erten Sarıkaya, H. ve Körükçü, Ö. (2020). Çocukların gözünden evdeki teknolojik araçlar. AVRASYA Uluslararası Araştırmalar Dergisi, 8(23), 175-201.

Jiao, W.Y., Wang, L.N., Liu, J., Fang, S.F., Jiao, F.Y., Pettoello-Mantovani, M. \& Somekh, E. (2020). Behavioral and emotional disorders in children during the COVID-19 epidemic. The Journal of Pediatrics, 221, 264-266. https://doi.org/10.1016/j.jpeds.2020.03.013

Karakaya, İ. (2012). Bilimsel Araştırma Yöntemleri. A. Tanrıöğren (Ed.), Bilimsel Araştırma Yöntemleri (3. Baskı) içinde (s. 57-83). Ankara: Anı Yayıncılık.

Lauricella, A. R., Wartella, E. \& Rideout, V. J. (2015). Young children's screen time: The complex role of parent and child factors. Journal of Applied Developmental Psychology, 36, 11-17. https://doi.org/10.1016/j.appdev.2014.12.001

Livingstone, S., Cagiltay, K. \& Ólafsson, K. (2015). EU Kids Online II Dataset: A cross-national study of children's use of the Internet and its associated opportunities and risks. British Journal of Educational Technology, 46(5), 988-992. https://doi.org/10.1111/bjet.12317

Lee, S., Ward, K.P., Chang, O.D. \& Downing, K.M. (2021). Parenting activities and the transition to home-based education during the COVID-19 pandemic. Children and Youth Services Review, 122(105585), 1-10. https://doi.org/10.1016/j.childyouth.2020.105585

Mart, M., \& Kesicioğlu, O. S. (2020). COVID-19 Pandemi Sürecinde Ailelerin Evde Oyun Oynamaya İlişkin Görüşleri. Electronic Turkish Studies, 15(4), 945-958. https://dx.doi.org/10.7827/TurkishStudies.44381

Medrano M., Cadenas-Sanchez C., Oses M., Arenaza L., Amasene M., \& Labayen I. (2021) Changes in lifestyle behaviours during the COVID-19 confinement in Spanish children: A longitudinal analysis from the MUGIproject. Pediatric Obesity. 16(4), 111. https://doi.org/10.1111/ijpo.12731

Muslu, G. K., \& Bolışık, B. (2009). Çocuk ve Gençlerde İnternet Kullanımı. TAF Preventive Medicine Bulletin, 8(5), 445-450.

Nathanson, A. I., Sharp, M. L., Aladé, F., Rasmussen, E. E., \& Christy, K. (2013). The relation between television exposure and theory of mind among preschoolers. Journal of Communication, 63(6), 1088-1108. https://doi.org/10.1111/jcom.12062

Nicola, M., Alsafi, Z., Sohrabi, C., Kerwan, A., Al-Jabir, A., Iosifidis, C., ... \& Agha, R. (2020). The socio-economic implications of the coronavirus pandemic (COVID-19): A review. 
International Journal of Surgery (London, England), 78, 185-193. https://doi.org/10.1016/j.ijsu.2020.04.018

Öner, D. (2020). Erken çocukluk döneminde teknoloji kullanımı ve dijital oyunlar: okul öncesi öğretmen görüşlerinin incelenmesi. İnönü Üniversitesi Eğitim Bilimleri Enstitüsü Dergisi, 7(14), 138-154.

Özcan, F. (2018). Okul öncesi eğitimi alan çocuklarda teknoloji kullanımının ve sosyal becerilerin bazı değişkenler açısından incelenmesi. Yüksek lisans tezi. Kastamonu: Kastamonu Üniversitesi. https://doi.org/10.29129/inujgse.715044

Özdemir, T. B. \& Çebi, A. (2020). Lise öğrencilerinin web 2.0 teknolojilerini kullanım durumlarmin incelenmesi. Journal of Kirsehir Education Faculty, 21(1), 1-33. https://doi.org/10.29299/kefad.2020.21.01.001

Pedagoji Okulu- Pedagog Adem Güneş. (2020, 27 Mart). Pedagoji okulu 103 - Korona virüsü çocuklara nasıl anlatılmalı [Video dosyası]. https://www.youtube.com/watch?v=36jXAmZ_JpQ

Rideout, V. (2017). The Common Sense census: Media use by kids age zero to eight. San Francisco, CA: Common Sense Media, 263-283.

Sayan, H. (2016). Okul öncesi eğitimde teknoloji kullanımı. 21. Yüzyılda Ĕğitim ve Toplum Ĕ̆itim Bilimleri ve Sosyal Araştırmalar Dergisi, 5(13), 67-83.

Tabachnick, B. G., Fidell, L. S. \& Ullman, J. B. (2007). Using multivariate statistics (5. Bask1). Boston, MA: Pearson.

Türkiye Cumhuriyeti İçişleri Bakanlığı. (2020). Şehir giriş/çıkış tedbirleri ve yaş sınırlaması. https://www.icisleri.gov.tr/sehir-giriscikis-tebirleri-ve-yas-sinirlamasi. Erişim. 8 Şubat 2021

Wilde, T. (2020). Online gaming surge: Steam breaks concurrent user record amid socail distancing mandates https://www.geekwire.com/2020/online-gaming-surge-steambreaks-concurrent-user-record-amidsocial-distancing-mandates/2020. Erişim. 17 Şubat 2021.

World Health Organization. (2020). WHO Director-General's opening remarks at the media briefing on COVID-19 - 11 March 2020. https://www.who.int/dg/speeches/detail/whodirector-general-s-opening-remarks-at-the-media-briefing-on-covid-19---11-march-2020

Yasacı, Z. \& Mustafaoglu, R. (2020). Dijital teknoloji maruziyeti çocukların uyku süresini etkiler mi? Ankara Medical Journal, 20(1), 11-22. https://dx.doi.org/10.5505/amj.2020.04880

Zehir, H., Zehir, K., Yalçın, F. A. \& Yalçın, M. (2019). Okul öncesi dönemde çocukların teknolojik araç kullanımı ve ailelerin bu araçların kullanımını sınırlandırmada kullandığı stratejiler. Current Research in Education, 5(2), 88-103. 